OPEN ACCESS

Edited by:

Kang-le Lu,

Jimei University, China

Reviewed by:

Shan He,

Huazhong Agricultural University,

China

Fotini Kokou

Wageningen University and Research,

Netherlands

*Correspondence:

Zhenhua Ma

zhenhua.ma@hotmail.com

${ }^{\dagger}$ These authors have contributed equally to this work

Specialty section:

This article was submitted to

Marine Fisheries, Aquaculture

and Living Resources,

a section of the journal

Frontiers in Marine Science

Received: 05 January 2021

Accepted: 23 March 2021

Published: 13 April 2021

Citation:

Fu Z, Zhou S, Yu G, Yang $R$, Han $M$ and $M a Z$ (2021) Influence of Non-protein Diets on Hepatic Metabolism and Endocrine

in Barramundi (Lates calcarifer).

Front. Mar. Sci. 8:649747.

doi: 10.3389/fmars.2021.649747

\section{Influence of Non-protein Diets on Hepatic Metabolism and Endocrine in Barramundi (Lates calcarifer)}

\author{
Zhengyi Fu ${ }^{1,2,3+}$, Shengjie Zhou ${ }^{1,2,3+}$, Gang Yu ${ }^{1,2,3}$, Rui Yang ${ }^{1,2,3}$, Mingyang Han ${ }^{1,2,3}$ and \\ Zhenhua Ma ${ }^{1,2,3 *}$
}

\begin{abstract}
'Tropical Aquaculture Research and Development Center, South China Sea Fisheries Research Institute, Chinese Academy of Fishery Sciences, Sanya, China, ${ }^{2}$ Key Laboratory of South China Sea Fishery Resources Exploitation and Utilization, Ministry of Agriculture and Rural Affairs, Guangzhou, China, ${ }^{3}$ Sanya Tropical Fisheries Research Institute, Sanya, China
\end{abstract}

This study evaluated the effects of different dietary non-protein energy sources on hepatic metabolism and endocrine of barramundi. Fish were fed iso-energy diets (18 MJ $\mathrm{kg}^{-1}$ ) with two types of non-protein energy source in the experimental group and a regular diet was used as the control. The feeding trial lasted 56 days. In the present study, CPT1 and SCD expression in fish fed high lipid diet were upregulated and liver lipid metabolism was more active than the control group. Serum biochemical parameters including serum glucose, serum triacylglycerol and serum cholesterol were significantly increased. The IGF-I and IGF-II expressions were significantly upregulated, and growth performances were improved in fish fed the high lipid diet. When barramundi were fed with the high carbohydrate diet, GK expression was downregulated and CPEPCK expression was upregulated, indicating that glycogen might accumulate in liver. The fluctuation of serum biochemical parameters and the growth performance were not significantly different compared to the control group. In conclusion, high lipid diet can shorten the raising period, but it causes the change of metabolic level and the increase of useless adipose tissue; The high carbohydrate diet did not significantly improve the growth performance, and no significant metabolic abnormalities were observed, indicating that carbohydrate has the potential to be the feed energy supply source for juvenile barramundi. The results provide insights for further understanding the availability of non-protein energy sources in the diet of juvenile barramundi.

Keywords: Lates calcarifer, non-protein energy sources, growth performance, serum biochemical parameters, metabolism, endocrine

\section{INTRODUCTION}

In intensive aquaculture, feed supply is the main component of production costs, and protein is the most expensive ingredient in most fish diets because of the non-renewability of fish meal and the presence of anti-nutrient factors in plant proteins (Muzinic et al., 2006; Cashion et al., 2017). Energy density of feed is generally increased by increasing the protein content, but high protein content is not only increases the cost of raising but also has negative impacts of environment due to potential 
nitrogenous losses such as residues and feces (Dosdat, 2001; Lazzari and Baldisserotto, 2008). An increase in the proportion of lipids and carbohydrates added to the feed effectively alleviates this problem, with some additional benefits. Lipids are known to be the major non-protein energy with high energy density in fish feed. Dietary lipids are considerable sources of essential fatty acids for fish, and some researchers have indicated that appropriate dietary lipid content can improve the quality of the end product (NRC, 2011). Carbohydrates are more attractive and potential included in diet because of their abundant availability and cheap (Wilson, 1994). The addition of this nutrient also has a beneficial effect to the pelleting quality of feed (Thomas et al., 1998).

Animals have developed metabolic system accurate and complex enough to accommodate to diversified nutritional states in their natural environment (Buettner et al., 2007; Soengas, 2014; Gyamfi et al., 2019). The changes in the metabolism are a tool that reflect the adaptability to different dietary conditions (Moraes and Bidinotto, 2004; Bibiano Melo et al., 2006). To elucidate the reasons for the variation in metabolism, the understanding of the change in the key enzymes involved in each metabolic pathway is essential. Previous studies have shown that feed nutrition would cause changes in hepatic function by regulating lipid metabolism, thereby changing cell function (Li et al., 2016; Meng et al., 2018). High dietary carbohydrate: lipid ratios (>3.41) by increases de novo lipogenesis and reduces FA $\beta$-oxidation and lipoprotein clearance in the liver, thereby accelerating the liver lipid deposition of juvenile tilapia, Oreochromis niloticus (Xie et al., 2017). To maintain the optimum health condition in carnivorous fish, it is necessary to understand the adaptative strategy of energy metabolism and metabolic feedback in the feeding practice.

As an aquatic species widely cultivated in Australia and Asian countries, barramundi (Lates calcarifer) has the characteristics of fast growth, easy propagation and domestication (Liu et al., 2018; Ma et al., 2018, 2019). Barramundi also has a long history of breeding and research, as well as extensive studies on its lipid and carbohydrate requirements. There are two kinds of common feed formulation for barramundi in Australia that are implemented by adjusting the protein and lipid levels, one is low energy density (15 MJ/k digestible energy, 46\% digestible protein, 12\% lipid) and the other is medium energy density (18 $\mathrm{MJ} / \mathrm{k}$ digestible energy, $\sim 40 \%$ digestible protein, $20 \%$ lipid) (Glencross, 2006, 2008). Studies have tried to raise carbohydrate levels to save feed costs for barramundi. A recommended protein level is $42.5 \%$, lipid level is $6-12 \%$, and the carbohydrate level is raised to $20 \%$ of the feed, and this will not significantly affect the growth of barramundi (Catacutan and Coloso, 1997). However, little investigation has been paid to the metabolism of this species, and the adaptive strategies to non-protein energy sources intake have not been well studied. In the present study, fish oil and $\alpha$-starch were used as the potential energy source to evaluate the endocrine status and hepatic metabolism of barramundi to dietary lipids and carbohydrate. Results from the present study could pave the way to further understand on energy metabolism of barramundi and provide a basis for optimizing feed formula of barramundi with a cheaper dietary source.

\section{MATERIALS AND METHODS}

\section{Experimental Diets}

Three iso-energy diets (Table 1) referenced from previous study (Fu et al., 2019), the control group (C) used the diet formula according to crude protein $475 \mathrm{~g} \mathrm{~kg}^{-1}$, crude lipid $100 \mathrm{~g} \mathrm{~kg}^{-1}$, and nitrogen-free extract $180 \mathrm{~g} \mathrm{~kg}^{-1}$ (Glencross et al., 2017). In the experimental group, fish oil and $\alpha$-starch were used as the source of lipid and carbohydrate, respectively (NRC, 2011). The crude lipid in the high lipid group (HL) increased to $160 \mathrm{~g} \mathrm{~kg}^{-1}$, and the nitrogen-free extract in the high carbohydrates group (HC) increased to $220 \mathrm{~g} \mathrm{~kg}^{-1}$. The preparation and preservation methods of the feed were also referred to in previous study (Fu et al., 2019).

\section{Experiment Design and System}

The same batch of Juvenile barramundi (33.69 $\pm 3.63 \mathrm{~g}$, $12.08 \pm 2.13 \mathrm{~cm}$ ) were obtained from Tropical Aquaculture Research and Development Center, Sanya, China, and grown in an indoor seawater recirculating system being fed a commercial feed (Santong Bio-engineering Co., Ltd., Weifang, China). Fish were grouped and weaned according to previous study (Fu et al., 2019). A total of 117 fish were randomly divided to 9

TABLE 1 | Feed composition $\left(\mathrm{g} \mathrm{kg}^{-1}\right)$, proximate composition of the diets (air-dry basis $\mathrm{g} \mathrm{kg}^{-1}$ ) and gross energy content $\left(\mathrm{MJ} \mathrm{kg}^{-1}\right)$ in three experimental diets (Fu et al., 2019).

\begin{tabular}{|c|c|c|c|}
\hline Ingredients & C & HL & $\mathrm{HC}$ \\
\hline Fish meal & 560 & 560 & 560 \\
\hline Peeled soybean meal & 236 & 176 & 186 \\
\hline$\alpha$-starch & 100 & 100 & 150 \\
\hline Fish oil & 60 & 120 & 60 \\
\hline Choline chloride & 2 & 2 & 2 \\
\hline Vitamin premix ${ }^{a}$ & 10 & 10 & 10 \\
\hline Mineral premix ${ }^{b}$ & 10 & 10 & 10 \\
\hline Yttrium oxide & 2 & 2 & 2 \\
\hline Calcium dihydrogen phosphate & 10 & 10 & 10 \\
\hline Ethoxy quin & 10 & 10 & 10 \\
\hline Total & 1,000 & 1,000 & 1,000 \\
\hline \multicolumn{4}{|l|}{ Proximate composition } \\
\hline Dry matter & 929.9 & 914.1 & 932 \\
\hline Crude protein & 474.9 & 445.7 & 451.4 \\
\hline Lipid & 99.9 & 153.1 & 94 \\
\hline Ash & 173.6 & 167 & 167.2 \\
\hline Nitrogen-free extract & 179.99 & 145.04 & 218.10 \\
\hline Gross energy(MJ kg $\left.{ }^{-1}\right)$ & 18.26 & 19.08 & 18.13 \\
\hline
\end{tabular}

a Vitamin premix ( $m g \mathrm{~kg}^{-1}$ diet or specified): vitamin A 9000000 (IU $\mathrm{kg}^{-1}$ diet), vitamin D 2500000 (IU kg-1 diet), vitamin K3 600 (IU kg $\mathrm{kg}^{-1}$ diet), vitamin E 500 (IU kg-1 diet), vitamin B1 3200, vitamin B2 1 0900, vitamin B5 2 0000, vitamin B6 5000, vitamin B12 1160, vitamin C 5 0000, niacin 400, folic acid 50,calcium pantothenate 200, phaseomannite 1500, biotin 2.

${ }^{b}$ Mineral premix $\left(\mathrm{mg} \mathrm{kg}^{-1}\right.$ diet or specified): $\mathrm{MgSO} 4.7 \mathrm{H} 2 \mathrm{O} 300 ; \mathrm{KCl} 70 ; \mathrm{KI} \mathrm{1.5}$; ZnSO4.7H2O 14; MnSO4.4H2O 3; CuCl2 5; CoCl2.6H2O 0.5; FeSO4.7H2O 15; $\mathrm{KH} 2 \mathrm{PO} 4 . \mathrm{H} 2 \mathrm{O} 4.5$ ( $\mathrm{g} \mathrm{kg}^{-1}$ diet); $\mathrm{CaCl} 22.8\left(\mathrm{~g} \mathrm{~kg}^{-1}\right.$ diet). The dietary energy was calculated as protein: 23. $64 \mathrm{MJ} \cdot \mathrm{kg}^{-1}$,lipid: 39. $54 \mathrm{MJ} \cdot \mathrm{kg}^{-1}$,carbohydrate: 17. $15 \mathrm{MJ} \cdot \mathrm{kg}^{-1}$. C, Control; HL, High lipid; HC, High carbohydrate. 
experimental tanks (fiber glass, $800 \mathrm{~L}$ ) for a 12 day acclimation. Each experimental tank contained 13 fish and experimental feed was randomly assigned to the experimental tank. The experiment lasted 8 weeks. The experiment was conducted in outdoor seawater tanks with filtered natural seawater. Fish were fed ad libitum twice a day at 08:00 and 16:00 h until apparent satiation on the basis of visual observation, and the feed consumed per tank were recorded. One hour after fed, the residual feeds and feces were sucked away. During the experimental period, the water quality parameters were measured daily and maintained at dissolved oxygen $>7.0 \mathrm{mg} \mathrm{L}^{-1}$, ammonia nitrogen $<0.1 \mathrm{mg} \mathrm{L}^{-1}$, nitrite nitrogen $<0.02 \mathrm{mg} \mathrm{L}^{-1}$, salinity $33 \pm 1 \%$ and $\mathrm{pH}$ 7.8. The fish were reared and fed the diets under natural daylight cycle.

\section{Sampling}

At the time of the experiment ending, all fish were anaesthetized in $7 \mathrm{mg} \mathrm{L}^{-1}$ eugenol (Shangchi Dental Material Co., Ltd., Changshu, China), weighed to estimate growth performance and three fish were sampled from each tank (i.e., nine fish per treatment) for somatic parameters, biochemical and gene expression analyses. Blood was withdrawn from the caudal vein by a sterile injector $(1 \mathrm{~mL})$, allowed to stand at room temperature for $4 \mathrm{~h}$, centrifuged at $3,500 \times \mathrm{g}$ for $10 \mathrm{~min}$ at $4^{\circ} \mathrm{C}$, and the supernatant was collected and then stored at $-80^{\circ} \mathrm{C}$ for further analysis. Thereafter, whole body, viscera, liver and intraperitoneal fat were weighed for determination of viscera ratio (VR), hepatosomatic index (HSI), intraperitoneal fat ratio (IPF). Liver tissues were snap-frozen in liquid nitrogen, then preserved at $-80^{\circ} \mathrm{C}$ until use.

\section{Proximate Composition Analysis}

The proximal compositions of the diet, fish body and muscle samples were determined based on previous study (Glencross et al., 2017; Ma et al., 2019). Moisture was determined by oven dry to a constant weight at $103^{\circ} \mathrm{C}$ in an air-blowerdriven drying closet (Nocchi Instrument Co., Ltd., China). Crude protein content $(\mathrm{N} \times 6.25)$ was determined using a rapid $\mathrm{N}$ exceed (Elementar Co., Ltd., Germany). Ash (\% dry weight) was quantified by combustion at $550^{\circ} \mathrm{C}$ in a muffle furnace (Laboratory Instrument Co., Ltd., China). Crude lipid (\% dry weight) was determined by ether extraction using a Soxtec System (Zhejiang Tuopu Instrument Co., Ltd., China).

\section{Serum Biochemical Parameters Analysis}

The serum biochemical parameters were determined according to the manufacturer's instructions using commercial kits (Nanjing Jiancheng Bioengineering Institute, Nanjing, China) i.e., glucose(GLU): Glucose Oxsidase-Peroxidase Aminoantypirin method; triglycerides(TG): Phosphate oxidasePeroxidase Aminoantypirin method; total cholesterol(TC): Cholesterol Oxidase-Peroxsidase Aminoantypirin method; high-density lipoprotein cholesterol(HDL-C) and low-density lipoprotein cholesterol (LDL-C): direct method. All serum biochemical parameters analyses were performed in triplicate.

\section{Gene Expression Analysis}

Methods for RNA extraction and cDNA synthesis experiments were refined based on the methods published at Cold Spring Harbor Laboratory (Green and Sambrook, 2012). Total RNA was extracted using TRIzol (Invitrogen, United States). RNA integrity and concentration were verified by agarose gel electrophoresis and spectrophotometry (Bioteke Corporation Co., Ltd., China). The RNA was immediately used for cDNA synthesis. Subsequently, reverse transcription was performed on $1 \mu \mathrm{g}$ of total RNA using TransScript-Uni One-Step gDNA Removal and cDNA Synthesis SuperMix (Transgen Biotech Co., Ltd., China) following the manufacturer's instructions. The synthesized cDNA samples were stored at $-20^{\circ} \mathrm{C}$ until further use.

The genes chosen for analysis by qPCR were selected from the L. calcarifer NCBI database ${ }^{1}$. The sequences of specific primer pairs and genes accession numbers are shown in Table 2. The specific primers of ELOVL fatty acid elongase 5 (ELOVL5), fatty acid desaturase 2 (FADS2), cytosolic phosphoenolpyruvate carboxykinase (cPEPCK), insulin like growth factor 1 (IGFI), insulin like growth factor 2 (IGF-II) and actin beta $(\beta$-actin) were designed using the Primer Premier 5 program. The primers of stearoyl CoA deasaturase (SCD), carnitine palmitoyl transferase 1 (CPT1), ATP-citrate synthase (ACLY) and glucokinase (GK) were previously designed and validated

${ }^{1}$ https://www.ncbi.nlm.nih.gov/

TABLE 2 | Primers of SCD, CPT1, ELOVL5, FADS2, ACLY, GCK, CPEPCK, IGF-I, IGF-II, and $\beta$-actin genes in barramundi used in QPCR.

\begin{tabular}{|c|c|c|c|}
\hline $\begin{array}{l}\text { Gene } \\
\text { abbreviation }\end{array}$ & Primer sequence $\left(5^{\prime}-3^{\prime}\right)$ & $\begin{array}{c}\text { Amplicon } \\
\text { size (bp) }\end{array}$ & $\begin{array}{c}\text { Accession } \\
\text { number }\end{array}$ \\
\hline \multicolumn{4}{|l|}{$\begin{array}{l}\text { Metabolism } \\
\text { genes }\end{array}$} \\
\hline \multirow[t]{2}{*}{ SCD } & F: CCTGGTACTTCTGGGGTGAA & 217 & XM_018696772.1 \\
\hline & R: AAGGGGAATGTGTGGTGGTA & & \\
\hline \multirow[t]{2}{*}{ CPT1 } & F: TGATGGTTATGGGGTGTCCT & 186 & XM_018678316.1 \\
\hline & R: CGGCTCTCTTCAACTTTGCT & & \\
\hline \multirow[t]{2}{*}{ ELOVL5 } & F: ATCCAGTTCTTCTTAACCGT & 277 & GQ214180.1 \\
\hline & R: GGTTTCTCAAATGTCAATCCAC & & \\
\hline \multirow[t]{2}{*}{ FADS2 } & F: TCATACTACCTTCGCTACTTCTC & 104 & GU047383.2 \\
\hline & R: ACAAACCAGTGACTCTCCAG & & \\
\hline \multirow[t]{2}{*}{ ACLY } & F: CAACACCATTGTCTGTGCTC & 271 & XM_018703332.1 \\
\hline & R: GAAATGCTGCTTAACAAAGTCC & & \\
\hline \multirow[t]{2}{*}{ GK } & F: CTGGTGTGATCAACCGAATG & $179>$ & XM_018673057.1 \\
\hline & R: АССАСТССССТССТСТGACT & & \\
\hline \multirow[t]{2}{*}{ CPEPCK } & F: TCCGCCATCGGCTACCT & $119>$ & XM_018678244.1 \\
\hline & R: TCCTCCACСTCCСTITGC & & \\
\hline
\end{tabular}

\section{Growth}

hormone genes

|GF-|

F: TGTGGACGAGTGCTGCTT

144

EU136176.1

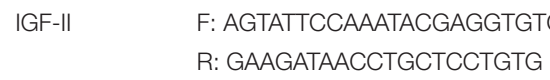

R: TGCCCTGCGGTACTAACCT

131 XM_018664155.1

Control gene

$\beta$-actin

F: AACCAAACGCCCAACAACT 


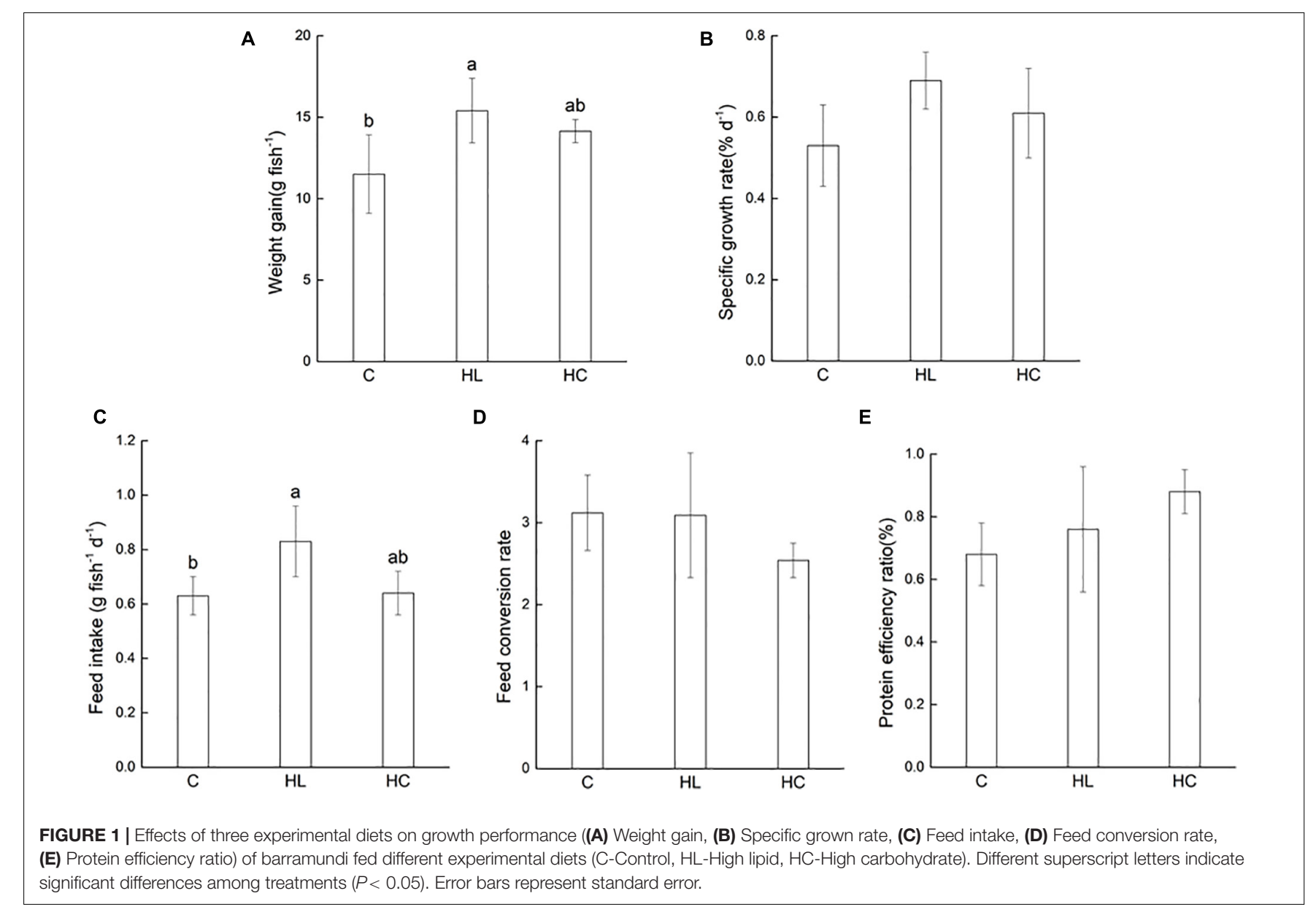

by Wade et al. (2014). The qPCR was amplified in a Realtime qPCR machine (Hangzhou Longgene Scientific Instrument Co., Ltd., China) using SYBR Green (Tiangen Biotech Co., Ltd., China) following the manufacturer's recommendations. Before the Real-time qPCR experiments, the specificity and efficiency of the primes above were detected. Each primer product was validated by melt-curve analysis to ensure only specific products were obtained with no formation of primer dimers. Constructing standard curves using serial dilution of cDNA. After verification of PCR efficiency to be around 100\%, and Pearson's coefficients of determination $\left(\mathrm{R}^{2}\right)>0.98$. The $20 \mu \mathrm{l}$ of reaction including $10 \mu 12 \times$ RealUniversal PreMix, $0.6 \mu 1$ of each primer $(10 \mu \mathrm{M})$ and $2 \mu \mathrm{l}$ of diluted cDNA was initially denatured at $95^{\circ} \mathrm{C}$ for $15 \mathrm{~min}$ and then amplified for 40 cycles $\left(95^{\circ} \mathrm{C}, 10 \mathrm{~s}, 58^{\circ} \mathrm{C}, 20 \mathrm{~s}\right.$, and $72^{\circ} \mathrm{C}, 30 \mathrm{~s}$ ). Each assay was repeated three times in this study. No template control (NTC) was included with each assay to verify that PCR master mixes were free of contamination. The ${ }^{\Delta \Delta} \mathrm{C}_{t}$ method was used to calculate the relative expression with $\beta$-actin as a reference gene, and normalized as a control (Green and Sambrook, 2012).

\section{Calculations and Statistical Analysis}

Specific growth rate (SGR), Feed conversion ratio (FCR), Feed intake (FI), Protein efficiency ratio (PER), Condition factor
(CF), Viscera ratio (VR), Hepatosomatic index (HIS) and Intraperitoneal fat ratio (IPF) were calculated by referring to the method of Fu and Ma (Fu et al., 2019; Ma et al., 2019).

The data were presented as the mean \pm standard deviation (SD). Statistical analyses were carried out by PASW Statistics (version 18). Assumptions of homogeneity of variances were checked using Levene's equal variance test. The dissimilarities between different groups were conducted by one-way ANOVA and LSD test, and the level of significance was set at $P<0.05$. All percentage data were transformed using square root to satisfy the assumptions of ANOVA.

\section{RESULTS}

\section{Growth Performance}

The fish growth performance was presented in Figure 1. The SGR, FCR and PER were not significantly different among the three groups of Lates calcarifer. Only WG and FI showed significant difference $(P<0.05)$ and the trend was similar, among which the $\mathrm{HL}$ and $\mathrm{C}$ treatments showed significant difference $(P<0.05)$, but HC showed no significant difference with the other two groups $(P>0.05)$. 


\section{Proximate Composition and Somatic Parameters}

In order to better explain the experimental results in conjunction with other data, data on Proximate composition and somatic parameters were referenced from previous study (Fu et al., 2019). There was no significant difference in moisture content among the three groups $(P>0.05$, Table 3$)$. The crude protein in the whole body and muscle of the HL group was significantly lower than that of the other two groups $(P<0.05)$, and the crude fat was significantly higher than that of the other two groups $(P<0.05)$. Nevertheless, the consistency between the whole body and the muscle was not reflected in the crude ash content, and the crude ash content in the HL group was significantly lower than that in the other two groups $(P<0.05)$. In the muscle, the coarse ash content was $\mathrm{C}>\mathrm{HL}>\mathrm{HC}$, and there was a significant difference between the $\mathrm{C}$ and $\mathrm{HL}$ groups $(P<0.05)$. There was no significant difference in the condition factor (CF) and the viscera ratio (VR) in all groups $(P>0.05$, Table 3$)$. The HL was the highest group in the hepatosomatic index (HSI) and intraperitoneal fat ratio (IPF). Meanwhile, the HSI was significantly different between the HL and HC groups, and the IPF in the HL group was significantly different from that in the other two groups $(P<0.05)$.

\section{Serum Biochemical Parameters Analysis}

GLU, TG, TC, HDL-C, and LDL-C were significantly affected by experimental diets $(P<0.05$, Table 4$)$, and the highest value was found in the HL group.

TABLE 3 | Effects of three experimental diets on body composition and somatic parameters in barramundi [Partly referred to Fu et al. (2019)].

\begin{tabular}{lccc}
\hline Items & \multicolumn{3}{c}{ Experimental diets } \\
\cline { 2 - 4 } & C & HL & HC \\
\hline Whole body composition & & & \\
Moisture contect\% & $70.41 \pm 0.75$ & $67.94 \pm 1.03$ & $68.81 \pm 2.06$ \\
Crude protein(N\% $\times 6.25)$ & $63.19 \pm 0.30^{\mathrm{a}}$ & $54.27 \pm 1.25^{\mathrm{c}}$ & $61.30 \pm 0.19^{\mathrm{b}}$ \\
Ash content\% DW & $18.17 \pm 0.24^{\mathrm{a}}$ & $16.92 \pm 0.21^{\mathrm{b}}$ & $18.31 \pm 0.13^{\mathrm{a}}$ \\
Crude lipid\% DW & $18.13 \pm 0.44^{\mathrm{c}}$ & $26.89 \pm 0.39^{\mathrm{a}}$ & $20.11 \pm 0.53^{\mathrm{b}}$ \\
Muscle composition & & & \\
Moisture contect\% & $78.54 \pm 1.02$ & $78.08 \pm 2.98$ & $77.80 \pm 0.39$ \\
Crude protein(N\% $\times 6.25)$ & $90.07 \pm 1.03^{\mathrm{a}}$ & $88.04 \pm 0.75^{\mathrm{b}}$ & $90.34 \pm 0.73^{\mathrm{a}}$ \\
Ash content\% DW & $5.84 \pm 0.08^{\mathrm{a}}$ & $5.77 \pm 0.08^{\mathrm{ab}}$ & $5.66 \pm 0.06^{\mathrm{b}}$ \\
Crude lipid\% DW & $2.19 \pm 0.11^{\mathrm{b}}$ & $3.81 \pm 0.19^{\mathrm{a}}$ & $2.03 \pm 0.10^{\mathrm{b}}$ \\
Somatic parameters & & & \\
CF (g cm ${ }^{-3}$ ) & $3.42 \pm 0.05$ & $3.62 \pm 0.04$ & $3.39 \pm 0.47$ \\
VR (\%) & $8.28 \pm 0.47$ & $9.46 \pm 0.66$ & $8.04 \pm 2.22$ \\
HIS (\%) & $1.47 \pm 0.27^{\mathrm{ab}}$ & $1.96 \pm 0.27^{\mathrm{a}}$ & $1.36 \pm 0.25^{\mathrm{b}}$ \\
IPF (\%) & $1.91 \pm 0.24^{\mathrm{b}}$ & $3.84 \pm 0.59^{\mathrm{a}}$ & $1.48 \pm 0.32^{\mathrm{b}}$ \\
\hline
\end{tabular}

Data are given as the mean $\pm S D$. In the same row, values with same small letter superscripts or no letter superscripts mean no significant difference $(P>0.05)$; different small letter superscripts mean significant difference $(P<0.05)$.

CF, Condition factor; VR, Viscera ratio; HSI, Hepatosomatic index; IPF, Intraperitoneal fat ratio.

\section{Gene Expression of Liver}

In fatty acid metabolism genes, the SCD, CPT1, fasd2, and ACLY expressions in the HC group were significantly upregulated $(P<0.05)$, while the ELOVL5 expression showed no significant difference among treatments $(P>0.05$, Figure 2A). In glucose metabolism genes, the acyl and $\mathrm{CPEPCK}$ expressions in the HC group were significantly upregulated $(P<0.05)$, and the GK expression in the $\mathrm{HL}$ and $\mathrm{HC}$ groups were significantly downregulated $(P<0.05$, Figure $2 B$ ). In growth hormone genes, the IGF-I and IGF-II expression levels were similar in each treatment. The expressions of IGF-I and IGF-II were significantly upregulated in the HL group, while those were significantly downregulated in the HC group $(P<0.05$, Figure 2C).

\section{DISCUSSION}

In the present study, the adaptive mechanisms of barramundi to high lipid (160 $\left.\mathrm{g} \mathrm{kg}^{-1}\right)$ or high carbohydrate $\left(220 \mathrm{~g} \mathrm{~kg}^{-1}\right)$ diets were evaluated to gain a better understanding on the metabolic strategy of non-protein energy sources in barramundi. There was found that different non-protein energy sources had effects on growth performance, food intake, somatic proximate composition and serum biochemical parameters. According to the hepatic expression level of metabolic genes, barramundi had different strategies for different non-protein energy sources.

\section{The Response of Barramundi to High Lipid Diet}

In fish, dietary lipids are an important source of essential fatty acids (FA) for regular growth, body functions, health and reproduction (Turchini et al., 2009). In this study, the whole body lipid content increased in the HL group. Consistently, the concentration of serum triglyceride and glucose also increased, indicating an active endogenous lipid transport (Chatzifotis et al., 2010), and the oxidative decomposition of lipid consumes a large amount of the intermediate product of glycolysis (aglycerophosphate), which blocks glycolysis and makes the serum glucose increase (Tzur et al., 1964). In addition, the increase in

TABLE 4 | Effects of three experimental diets on Serum biochemical parameters in barramundi.

\begin{tabular}{lccc}
\hline Items & \multicolumn{3}{c}{ Experimental diets } \\
\cline { 2 - 4 } & $\mathbf{C}$ & $\mathbf{H L}$ & HC \\
\hline $\mathrm{GLU}(\mathrm{mmol} / \mathrm{L})$ & $11.20 \pm 1.74^{\mathrm{b}}$ & $14.41 \pm 0.6^{\mathrm{a}}$ & $9.88 \pm 0.53^{\mathrm{b}}$ \\
$\mathrm{TG}(\mathrm{mmol} / \mathrm{L})$ & $1.44 \pm 0.01^{\mathrm{b}}$ & $1.72 \pm 0.08^{\mathrm{a}}$ & $1.33 \pm 0.03^{\mathrm{c}}$ \\
$\mathrm{TC}(\mathrm{mmol} / \mathrm{L})$ & $5.99 \pm 0.43^{\mathrm{ab}}$ & $6.43 \pm 0.53^{\mathrm{a}}$ & $5.14 \pm 0.40^{\mathrm{b}}$ \\
$\mathrm{HDL}-\mathrm{C}(\mathrm{mmol} / \mathrm{L})$ & $2.68 \pm 0.18^{\mathrm{ab}}$ & $2.98 \pm 0.21^{\mathrm{a}}$ & $2.51 \pm 0.80^{\mathrm{b}}$ \\
$\mathrm{LDL}-\mathrm{C}(\mathrm{mmol} / \mathrm{L})$ & $2.16 \pm 0.23^{\mathrm{ab}}$ & $3.03 \pm 0.31^{\mathrm{a}}$ & $1.85 \pm 0.06^{\mathrm{b}}$
\end{tabular}

Data are given as the mean $\pm S D$. In the same row, values with same small letter superscripts or no letter superscripts mean no significant differences $(P>0.05)$; different small letter superscripts mean significant differences $(P<0.05)$.

C, Control; HL, High lipid; HC, High carbohydrate. GLU, glucose; TG, triacylglycerol; TC, total cholesterol; HDL-C, high density lipoprotein cholesterol; LDL-C, low density lipoprotein cholesterol. 

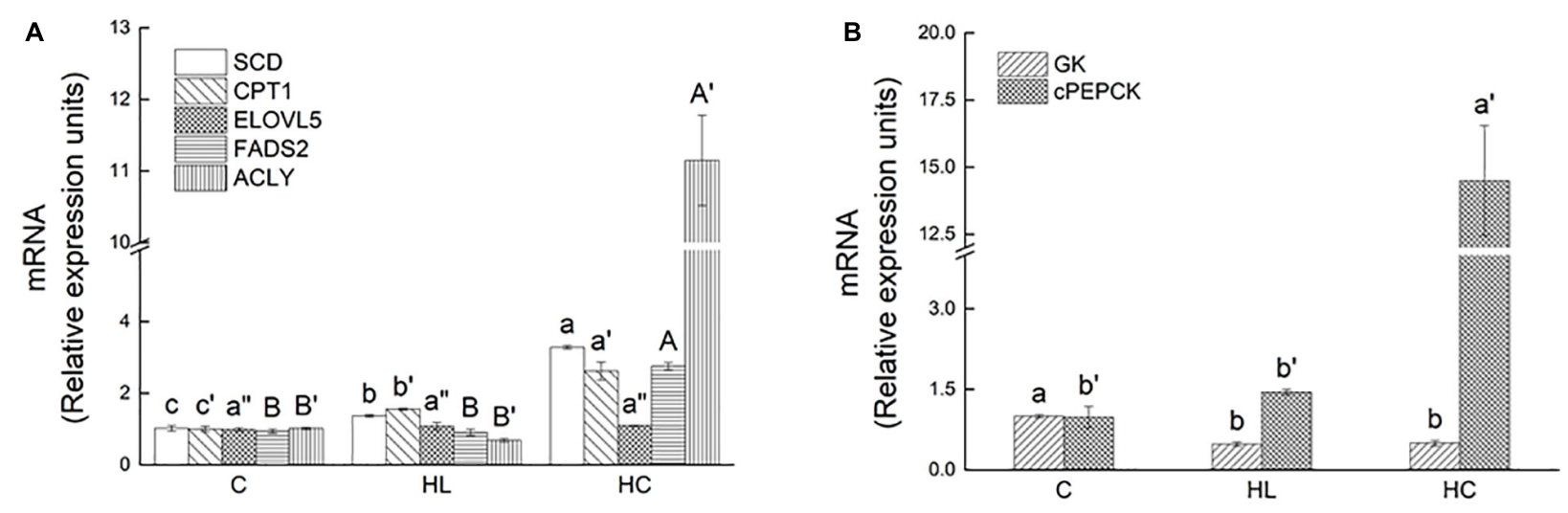

C

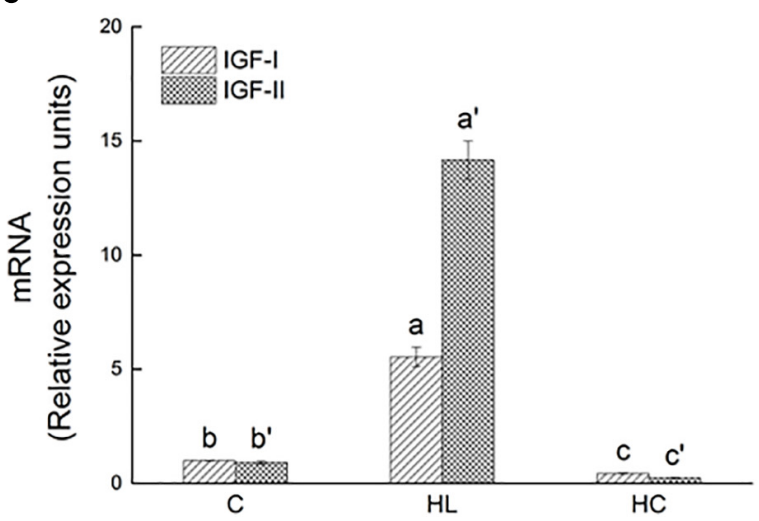

FIGURE 2 | Relative expression of lipid metabolism genes ((A) SCD, CPT1, ELOVL5, FADS2), carbohydrate metabolism genes ((B) ACLY, GK, CPEPCK) and Growth genes ((C) IGF-I, and IGF-II) in barramundi fed different experimental diets (C-Control, HL-High lipid, HC-High carbohydrate). Different superscript letters indicate significant differences among treatments $(P<0.05)$. Error bars represent standard error. (put the figures in a single column of three).

dietary lipid content leads to an increase in dietary energy density, which will induce fish to control energy intake by reducing food intake (Nankervis et al., 2000), but the result is just the opposite in the present study. We found that the enthusiasm of barramundi fed the high lipid diet was much higher than that of the other two groups. It can be speculated that the increase in food intake of the high lipid group may be due to the attraction of fish oil. It could also be that the high lipid diet was softer and palatable. The increase in feed intake directly leads to the increase in weight. Excessive dietary lipid intake induces to excessive fat deposition in muscle, liver and visceral cavity in fish (Martino et al., 2002; Alves Martins et al., 2007). In this study, the increase in weight includes two parts: effective weight gain and ineffective weight gain. Ineffective weight gain mainly refers to the accumulation of abdominal adipose tissue. It is calculated that the effective weight gain accounts for about a quarter of the total weight gain, which still leaves most of the energy devoted to the effective weight gain. Although the results of high lipid group showed metabolic abnormalities, they still gave us some enlightenment that adding appropriate amount of lipids in the diet could improve the feeding enthusiasm and growth performance of barramundi.

The result of certain important hepatic lipometabolic gene expressions showed that ELOVL5, FADS2, and ACLY had no significant difference compared with the control group, and CPT1 and SCD were significantly upregulated in the present study. CPT1 participates in the key step of mitochondrial fatty acid oxidation and can catalyze the transformation of fatty acyl- CoAs into fatty acid carnitines into the mitochondrial matrix (Kerner and Hoppel, 2000; Laura et al., 2018). SCD plays a significant part in the synthesis of unsaturated fatty acids (Flowers and Ntambi, 2008; Ardiyanti et al., 2012). The synthetic product contains oleate, it indispensable to the biosynthesis of triglycerides and other lipids (Hsieh et al., 2004; Gonzalez-Baró et al., 2007). Similar trends in the expression of the related genes of lipid metabolism were found in both grass carp (Ctenopharyngodon idellus) and tilapia (Oreochromis niloticus) (Li et al., 2016; Xie et al., 2017). In the present study, GK expression was significantly downregulated. The glucose phosphorylation reaction catalyzed by liver GK can provide the substrate for glycolysis, glycogenesis and the pentose phosphate pathway. It is very important for maintaining blood glucose homeostasis (Engelking, 2010). In mammals, fish oil in the diet would reduce the expression of GK at both the enzyme and mRNA levels. In fact, the principle is that long-chain polyunsaturated fatty acids (PUFA) in fish oil can inhibit hepatic GK gene expression (Jump et al., 1994; Jump and Clarke, 1999). Whether the cause of GK 
expression reduction in barramundi is similar to that in mammals remains to further investigation. The intrahepatic adaptations of barramundi in response to high lipid intake were to increase SCD, induce CPT1 and simultaneously reduce GK to cope with excessive lipid intake.

Insulin like growth factors (IGFs) are mitogenic peptides, and they are generally believed that their expression are regulated by Endogenous (nutritional state and humoral factors) and exogenous (temperature and photoperiod) factors (Duan, 1998; Tatar et al., 2003). The process of nutrition regulation of IGFs is firstly caused by the hypothalamus integrated nutritional status clues, which leads to the release of stimulant (growth hormonereleasing hormone) or inhibitor (somatostatins) signals to the anterior pituitary gland to produce somatotrophs, which then enters the blood circulation and binds to hepatic $\mathrm{GH}$ receptors to stimulate the compound of IGFs (Picha et al., 2008). Several studies have suggested that IGFs have a significant role in nutrient metabolism, growth and development of fish and can be judged by the liver mRNA expression (Rolland et al., 2015). In previous studies, expression of the IGF-I and IGF-II genes were proved to be positively correlated with growth performance in channel catfish (Ictalurus punctatus) (Peterson et al., 2005), clownfish (Amphiprion ocellaris) (Avella et al., 2009), and golden pompano (Trachinotus ovatus) (Tan et al., 2017). In this study, IGF-I and IGF-II in the HL group were significantly upregulated, and the gene expression was consistent with the growth performance (WG and SGR). The increase in growth performance seems to be related to the IPF. This association can also be explained by the upregulation of IGF-I, which also promotes the proliferation and differentiation of adipose tissue (Chang et al., 2016). Therefore, dietary lipids promote IGFs secretion, and thus have a positive impact on growth performance. Similar results were found in rainbow trout (Oncorhynchus mykiss) and Nile tilapia (Oncorhynchus niloticus) (Vera Cruz et al., 2006; Meng et al., 2019).

\section{The Response of Barramundi to High Carbohydrate Intake}

The effect of high carbohydrate diet on fat accumulation in barramundi was not as significant as that of high-fat diet, suggesting that energy may be stored in other forms, such as glycogen (Hemre et al., 2002). There was no significant change in blood glucose, indicating that barramundi could adapt to the high-carbohydrate diet used in the study, and the serum TG, TC, LDL-C, and HDL-C were all reduced in various degrees, indicating that the intake of high-carbohydrate diet inhibited the utilization and transport of lipids.

The mRNA expression of metabolic key enzyme was significantly regulated by the high carbohydrate diet, and the expression of key enzyme genes for lipid synthesis (Fasd2, ACLY, and SCD) and decomposition (CPT1) was upregulated. Particularly, SCD and CPT1 were also higher than those in the HL group. Dietary carbohydrate administration also promote lipogenesis (Kamalam et al., 2012). There are two routes to excess glucose after carbohydrate feeding, one is amassed in the form of glycogen, or converted to triglycerides through lipogenesis (Skiba-Cassy et al., 2009; Polakof et al., 2012). The increased transcripts of liver lipid metabolism gene induced by dietary carbohydrate were found in gilthead sea bream Sparus aurata and rainbow trout Oncorhynchus mykiss (Castro et al., 2016; Song et al., 2018). Although there is no direct link between lipogenesis and glucose metabolism, this pathway possibly play an important part in glucose homeostasis because excessive glucose is converted to fatty acids. GK expression was downregulated and PEPCK expression was upregulated. This indicates that the extra carbohydrate can be converted into glycogen in barramundi fed the high carbohydrate diet. In some species such as carp Cyprinus carpio, rainbow trout Oncorhynchus mykiss and perch Perca fluviatilis and, the hepatic GK activity rises with dietary carbohydrate (Borrebaek et al., 2003; Capilla et al., 2003; Encarnación et al., 2004), but our findings do not support these findings. As a carnivorous fish, barramundi are insensitive to dietary carbohydrates, and the regulation of GK expression level remains to be further studied. Thus, the intrahepatic adaptation of barramundi in response to high carbohydrate intake were induces glycogen accumulation (GK and cPEPCK), enhance lipid synthesis (fasd2, ACLY, and SCD) and induce mitochondrial FA oxidative (CPT1) to activate lipid metabolism.

In the expression of growth hormone gene, IGF-I and IGFII were downregulated, but there was no significant difference in the growth performance compared with the control group. The possible explanation is that the downregulation is not strong enough to affect growth or other factors like insulin, steroids and thyroid hormones, which allow the fine control of growth and adaptation to endogenous and external changes (Mommsen and Moon, 2001). The other hypothesis is that the increase of carbohydrate through $\alpha$-starch in high carbohydrate diets leads to a lower FI due to its poor palatability. This hypothesis, however, is in contrast to the attractivity of high lipid diets to fish oil which lead to a direct response of endocrine and growth changes (Picha et al., 2008). Therefore, further research on feed intake as well as the role of other hormones associated with growth regulation is required in future.

\section{CONCLUSION}

This study demonstrates that when barramundi were fed with a high lipid diet, liver lipid metabolism was more active than in the control group. Serum biochemical parameters were significantly increased, and muscle and intraperitoneal fat were significantly accumulated, leading to improvement of growth performance. When barramundi were fed with a high carbohydrate diet, glycogen in the liver has the tendency of accumulation. The fluctuation of serum biochemical parameters was not obvious, and the accumulation of muscle and intraperitoneal fat were also not clearly evidenced. The growth performance in the $\mathrm{HC}$ and HL treatments was not significantly different from that of the control group. The intake of high lipid and high carbohydrate diets caused significant changes in metabolism, revealing the 
mechanism of the response to non-protein energy sources of juvenile barramundi.

\section{DATA AVAILABILITY STATEMENT}

The original contributions presented in the study are included in the article/supplementary material, further inquiries can be directed to the corresponding author/s.

\section{ETHICS STATEMENT}

The animal study was reviewed and approved by the Animal Care and Use Committee of South China Sea Fisheries Research Institute, Chinese Academy of Fishery Sciences.

\section{REFERENCES}

Alves Martins, D., Afonso, L. O. B., Hosoya, S., Lewis-McCrea, L. M., Valente, L. M. P., and Lall, S. P. (2007). Effects of moderately oxidized dietary lipid and the role of vitamin $\mathrm{E}$ on the stress response in Atlantic halibut (Hippoglossus hippoglossus L.). Aquaculture 272, 573-580. doi: 10.1016/j.aquaculture.2007.08. 044

Ardiyanti, A., Abe, T., Tameoka, N., Kobayashi, E., Shoji, N., Ohtani, Y., et al. (2012). Effects of growth hormone gene polymorphism on lipogenic gene expression levels in diaphragm tissues of japanese black heifers. Asian Australas J. Anim. Sci. 25, 1055-1062. doi: 10.5713/ajas.2012.12029

Avella, M. A., Olivotto, I., Silvi, S., Place, A. R., and Carnevali, O. (2009). Effect of dietary probiotics on clownfish: a molecular approach to define how lactic acid bacteria modulate development in a marine fish. Am. J. Physiol.Regulatory Integr. Compar. Physiol. 298, R359-R371.

Bibiano Melo, J. F., Lundstedt, L. M., Metón, I., Baanante, I. V., and Moraes, G. (2006). Effects of dietary levels of protein on nitrogenous metabolism of Rhamdia quelen (Teleostei: Pimelodidae). Compar. Biochem. Physiol. A Mol. Integr. Physiol. 145, 181-187. doi: 10.1016/j.cbpa.2006.06.007

Borrebaek, B., Christophersen, B., and Sundby, A. (2003). Metabolic function of hepatic hexokinase in perch, Perca fluviatilis. Aquac. Res. 34, 235-239. doi: 10.1046/j.1365-2109.2003.00809.x

Buettner, R., Schölmerich, J., and Bollheimer, L. C. (2007). High-fat diets: modeling the metabolic disorders of human obesity in rodents. Obesity 15, 798-808. doi: 10.1038/oby.2007.608

Capilla, E., Médale, F., Navarro, I., Panserat, S., Vachot, C., Kaushik, S., et al. (2003). Muscle insulin binding and plasma levels in relation to liver glucokinase activity, glucose metabolism and dietary carbohydrates in rainbow trout. Regulatory Peptides 110, 123-132. doi: 10.1016/s0167-0115(02)00212-4

Cashion, T., Le Manach, F., Zeller, D., and Pauly, D. (2017). Most fish destined for fishmeal production are food-grade fish. Fish Fish. 18, 837-844. doi: 10.1111/ faf. 12209

Castro, C., Corraze, G., Firmino-Diógenes, A., Larroquet, L., Panserat, S., and Oliva-Teles, A. (2016). Regulation of glucose and lipid metabolism by dietary carbohydrate levels and lipid sources in gilthead sea bream juveniles. Brit. J. Nutr. 116, 19-34. doi: 10.1017/s000711451600163x

Catacutan, M. R., and Coloso, R. M. (1997). Growth of juvenile Asian seabass, Lates calcarifer, fed varying carbohydrate and lipid levels. Aquaculture 149, 137-144. doi: 10.1016/s0044-8486(96)01432-9

Chang, H. R., Kim, H. J., Xu, X., and Ferrante, A. W. (2016). Macrophage and adipocyte IGF1 maintain adipose tissue homeostasis during metabolic stresses. Obesity 24, 172-183. doi: 10.1002/oby.21354

Chatzifotis, S., Panagiotidou, M., Papaioannou, N., Pavlidis, M., Nengas, I., and Mylonas, C. C. (2010). Effect of dietary lipid levels on growth, feed utilization, body composition and serum metabolites of meagre (Argyrosomus regius) juveniles. Aquaculture 307, 65-70. doi: 10.1016/j.aquaculture.2010.07.002

\section{AUTHOR CONTRIBUTIONS}

ZM and GY: conceptualization. SZ: experimental operation. ZF, SZ and MH: field sampling. ZF and RY: sample determination. ZF: writing-original draft preparation. ZM: writing-review and editing. All authors read and approved the final manuscript.

\section{FUNDING}

This study was supported by the Central Public-interest Scientific Institution Basal Research Fund (CAFS No. 2020TD55), Guangxi Innovation Driven Development Special Fund Project (Grant No. Guike AA18242031), Central Public-interest Scientific Institution Basal Research Fund, South China Sea Fisheries Research Institute (Grant No. CAFS-2018ZD01).

Dosdat, A. (2001). Environmental impact of aquaculture in the Mediterranean: nutritional and feeding aspects. Cah Options Mediterr. 55, 23-36.

Duan, C. (1998). Nutritional and developmental regulation of Insulin-like growth factors in fish. J. Nutr. 128, 306S-314S.

Encarnación, C., Françoise, M., Stephane, P., Christiane, V., Paulo, R., Emidio, G., et al. (2004). Response of hexokinase enzymes and the insulin system to dietary carbohydrates in the common carp, Cyprinus carpio. Reprod. Nutr. Dev. 44, 233-242. doi: 10.1051/rnd:2004027

Engelking, L. (2010). Overview of Carbohydrate Metabolism. Amsterdam: Academic Press.

Flowers, M. T., and Ntambi, J. M. (2008). Role of stearoyl-coenzyme a desaturase in regulating lipid metabolism. Curr. Opin. Lipidol. 19, 248-256. doi: 10.1097/ mol.0b013e3282f9b54d

Fu, Z., Yang, R., Chen, X., Qin, J. G., and Ma, Z. (2019). Dietary non-protein energy source regulates antioxidant status and immune response of barramundi (Lates calcarifer). Fish Shellfish Immun. 95, 697-704. doi: 10.1016/j.fsi.2019.11.018

Glencross, B. (2006). The nutritional management of barramundi, Lates calcarifera review. Aquacult. Nutr. 12, 291-309. doi: 10.1111/j.1365-2095.2006.00410.x

Glencross, B. D. (2008). A factorial growth and feed utilization model for barramundi, Lates calcarifer based on Australian production conditions. Aquacult. Nutr. 14, 360-373. doi: 10.1111/j.1365-2095.2007.00543.x

Glencross, B. D., Blyth, D., Bourne, N., Cheers, S., Irvin, S., and Wade, N. M. (2017). An analysis of partial efficiencies of energy utilisation of different macronutrients by barramundi (Lates calcarifer) shows that starch restricts protein utilisation in carnivorous fish. Brit. J. Nutr. 117, 500-510. doi: 10.1017/ s0007114517000307

Gonzalez-Baró, M. R., Lewin, T. M., and Coleman, R. A. (2007). Regulation of triglyceride metabolism. II. function of mitochondrial GPAT1 in the regulation of triacylglycerol biosynthesis and insulin action. Am. J. Physiol. Gastrointestinal Liver Physiol. 292, G1195-G1199.

Green, M. R., and Sambrook, J. (2012). Molecular Cloning: a Laboratory Manual. New York: Cold Spring Harbor Laboratory Press.

Gyamfi, D., Ofori Awuah, E., and Owusu, S. (2019). Lipid Metabolism: an Overview. Cambridge, MA: Academic Press.

Hemre, G., Mommsen, T. P., and Krogdahl, ^ (2002). Carbohydrates in fish nutrition: effects on growth, glucose metabolism and hepatic enzymes. Aquacult. Nutr. 8, 175-194. doi: 10.1046/j.1365-2095.2002.00200.x

Hsieh, S. L., Chang, H. T., Wu, C. H., and Kuo, C. M. (2004). Cloning, tissue distribution and hormonal regulation of stearoyl-CoA desaturase in tilapia, Oreochromis mossambicus. Aquaculture 230, 527-546. doi: 10.1016/s00448486(03)00408-3

Jump, D. B., and Clarke, S. D. (1999). Regulation of gene expression by dietary fat. Annu. Rev. Nutr. 19, 63-90.

Jump, D. B., Clarke, S. D., Thelen, A., and Liimatta, M. (1994). Coordinate regulation of glycolytic and lipogenic gene expression by polyunsaturated fatty acids. J. Lipid Res. 35, 1076-1084. doi: 10.1016/s0022-2275(20)40103-8 
Kamalam, B. S., Medale, F., Kaushik, S., Polakof, S., Skiba-Cassy, S., and Panserat, S. (2012). Regulation of metabolism by dietary carbohydrates in two lines of rainbow trout divergently selected for muscle fat content. J. Exp. Biol. 215, 2567-2578. doi: 10.1242/jeb.070581

Kerner, J., and Hoppel, C. (2000). Fatty acid import into mitochondria. Biochimica et Biophysica Acta 1486, 1-17. doi: 10.1016/s1388-1981(00)00044-5

Laura, M., Bianca, X. G., Hong, C., and Yuan-Xiang, P. (2018). Epigenetic regulation of carnitine palmitoyltransferase 1 (Cptla) by high fat diet. Biochim. Biophys. Acta. Gene Regulatory Mech. 1862, 141-152. doi: 10.1016/j.bbagrm. 2018.12.009

Lazzari, R., and Baldisserotto, B. (2008). Nitrogen and phosphorus waste in fish farming. Bol. Inst. Pesca. 34, 591-600.

Li, A., Yuan, X., Liang, X., Liu, L., Li, J., Li, B., et al. (2016). Adaptations of lipid metabolism and food intake in response to low and high fat diets in juvenile grass carp (Ctenopharyngodon idellus). Aquaculture 457, 43-49. doi: 10.1016/j. aquaculture.2016.01.014

Liu, Y., Hu, J., Zhou, S., Yang, R., Qin, J., Ma, Z., et al. (2018). Effect of acute ammonia stress on antioxidant enzymes and digestive enzymes in barramundi Lates calcarifer Larvae. Israeli J. Aquac. Bamidgeh. 70, 1508-1519.

Ma, Z., Hassan, M. M., Allais, L., He, T., Leterme, S., Ellis, A. V., et al. (2018). Replacement of fishmeal with commercial soybean meal and EnzoMeal in juvenile barramundi Lates calcarifer. Aquac. Res. 49, 3258-3269. doi: 10.1111/ are. 13790

Ma, Z., Hassan, M. M., Allais, L., He, T., Leterme, S., Ellis, A., et al. (2019). Comparison of partial replacement of fishmeal with soybean meal and EnzoMeal on growth performance of Asian seabass Lates calcarifer. Compar. Biochem. Physiol. C Toxicol. Pharmacol. 216, 29-37. doi: 10.1016/j.cbpc.2018. 10.006

Martino, R. C., Cyrino, J. E. P., Portz, L., and Trugo, L. C. (2002). Effect of dietary lipid level on nutritional performance of the surubim, Pseudoplatystoma coruscans. Aquaculture 209, 209-218. doi: 10.1016/s0044-8486(01)00738-4

Meng, X., Li, S., Qin, C., Zhu, Z., Hu, W., Yang, L., et al. (2018). Intestinal microbiota and lipid metabolism responses in the common carp (Cyprinus carpio L.) following copper exposure. Ecotox. Environ. Saf. 160, 257-264. doi: 10.1016/j.ecoenv.2018.05.050

Meng, Y., Qian, K., Ma, R., Liu, X., Han, B., Wu, J., et al. (2019). Effects of dietary lipid levels on sub-adult triploid rainbow trout (Oncorhynchus mykiss): growth performance, digestive ability, health status and expression of growth-related genes. Aquaculture 513:734394. doi: 10.1016/j.aquaculture.2019.734394

Mommsen, T. P., and Moon, T. W. (2001). Hormonal Regulation of Muscle Growth. Cambridge, MA: Academic Press, 251-308.

Moraes, G., and Bidinotto, P. M. (2004). Digestive proteases of pacu, Piaractus mesopotamicus, fed on distinct protein-starch diets. J. Appl. Aquac. 15, 197-207. doi: 10.1300/j028v15n03_17

Muzinic, L. A., Thompson, K. R., Metts, L. S., Dasgupta, S., and Webster, C. D. (2006). Use of turkey meal as partial and total replacement of fish meal in practical diets for sunshine bass (Morone chrysops $\times$ Morone saxatilis) grown in tanks. Aquacult. Nutr. 12, 71-81. doi: 10.1111/j.1365-2095.2006.00387.x

Nankervis, L., Matthews, S. J., and Appleford, P. (2000). Effect of dietary nonprotein energy source on growth, nutrient retention and circulating insulin-like growth factor I and triiodothyronine levels in juvenile barramundi, Lates calcarifer. Aquaculture 191, 323-335. doi: 10.1016/s0044-8486(00)00436-1

NRC (2011). Nutrient Requirements of Fish and Shrimp. Washington DC: The National Academies Press.

Peterson, B. C., Waldbieser, G. C., and Bilodeau, L. (2005). Effects of recombinant bovine somatotropin on growth and abundance of mRNA for IGF-I and IGFII in channel catfish (Ictalurus punctatus). J. Anim. Sci. 83, 816-824. doi: $10.2527 / 2005.834816 \mathrm{x}$

Picha, M. E., Turano, M. J., Beckman, B. R., and Borski, R. J. (2008). Endocrine biomarkers of growth and applications to aquaculture: a minireview of growth hormone, insulin-like growth factor (IGF)-I, and IGF-binding proteins as potential growth indicators in fish. N. Am. J. Aquacult. 70, 196-211. doi: 10.1577/a07-038.1

Polakof, S., Panserat, S., Soengas, J. L., and Moon, T. W. (2012). Glucose metabolism in fish: a review. J. Compar. Physiol. B. 182, 1015-1045. doi: 10.1007/s00360-012-0658-7

Rolland, M., Dalsgaard, J., Holm, J., Gómez-Requeni, P., and Skov, P. V. (2015). Dietary methionine level affects growth performance and hepatic gene expression of GH-IGF system and protein turnover regulators in rainbow trout (Oncorhynchus mykiss) fed plant protein-based diets. Compar. Biochem. Physiol. B Biochem. Mol. Biol. 181, 33-41. doi: 10.1016/j.cbpb.2014.11.009

Skiba-Cassy, S., Lansard, M., Panserat, S., and Médale, F. (2009). Rainbow trout genetically selected for greater muscle fat content display increased activation of liver TOR signaling and lipogenic gene expression. Am. J. Physiol. Regulatory Integr. Compar. Physiol. 297, R1421-R1429. doi: 10.1152/physiolgenomics. 00114.2006

Soengas, J. L. (2014). Contribution of glucose- and fatty acid sensing systems to the regulation of food intake in fish. a review. Gen. Comp. Endocr. 205, 36-48. doi: 10.1016/j.ygcen.2014.01.015

Song, X., Marandel, L., Dupont-Nivet, M., Quillet, E., Geurden, I., and Panserat, S. (2018). Hepatic glucose metabolic responses to digestible dietary carbohydrates in two isogenic lines of rainbow trout. Biology Open. 7:32896.

Tan, X., Sun, Z., Huang, Z., Zhou, C., Lin, H., Tan, L., et al. (2017). Effects of dietary hawthorn extract on growth performance, immune responses, growthand immune-related genes expression of juvenile golden pompano (Trachinotus ovatus) and its susceptibility to Vibrio harveyi infection. Fish Shellfish Immun. 70, 656-664. doi: 10.1016/j.fsi.2017.09.041

Tatar, M., Bartke, A., and Antebi, A. (2003). The endocrine regulation of aging by insulin-like signals. Science 299, 1346-1351. doi: 10.1126/science.1081447

Thomas, M., van Vliet, T., and van der Poel, A. F. B. (1998). Physical quality of pelleted animal feed 3. Contribution of feedstuff components. Anim. Feed Sci. Technol. 70, 59-78. doi: 10.1016/s0377-8401(97)00072-2

Turchini, G. M., Torstensen, B. E., and Ng, W. (2009). Fish oil replacement in finfish nutrition. Rev. Aquacult. 1, 10-57. doi: 10.1111/j.1753-5131.2008.01001. $\mathrm{X}$

Tzur, R., Tal, E., and Shapiro, B. (1964). $\alpha$-Glycerophosphate as regulatory factor in fatty acid esterification. Biochim. Biophys. Acta 84, 18-23. doi: 10.1016/09266542(64)90096-4

Vera Cruz, E. M., Brown, C. L., Luckenbach, J. A., Picha, M. E., Bolivar, R. B., and Borski, R. J. (2006). Insulin-like growth factor-I cDNA cloning, gene expression and potential use as a growth rate indicator in Nile tilapia, Oreochromis niloticus. Aquaculture 251, 585-595. doi: 10.1016/j.aquaculture.2005.06.039

Wade, N. M., Skiba-Cassy, S., Dias, K., and Glencross, B. D. (2014). Postprandial molecular responses in the liver of the barramundi, Lates calcarifer. Fish Physiol. Biochem. 40, 427-443. doi: 10.1007/s10695-013-9854-y

Wilson, R. P. (1994). Utilization of dietary carbohydrate by fish. Aquaculture 124, 67-80. doi: 10.1016/0044-8486(94)90363-8

Xie, D., Yang, L., Yu, R., Chen, F., Lu, R., Qin, C., et al. (2017). Effects of dietary carbohydrate and lipid levels on growth and hepatic lipid deposition of juvenile tilapia, Oreochromis niloticus. Aquaculture 479, 696-703. doi: 10. 1016/j.aquaculture.2017.07.013

Conflict of Interest: The authors declare that the research was conducted in the absence of any commercial or financial relationships that could be construed as a potential conflict of interest.

Copyright (c) $2021 \mathrm{Fu}$, Zhou, Yu, Yang, Han and Ma. This is an open-access article distributed under the terms of the Creative Commons Attribution License (CC BY). The use, distribution or reproduction in other forums is permitted, provided the original author(s) and the copyright owner(s) are credited and that the original publication in this journal is cited, in accordance with accepted academic practice. No use, distribution or reproduction is permitted which does not comply with these terms. 